\title{
Practical Food Safety Interventions for Dairy Production
}

\author{
P. L. Ruegg \\ Department of Dairy Science \\ University of Wisconsin \\ 1675 Observatory $\mathrm{Dr}$. \\ Madison 53706
}

\begin{abstract}
Consumers are increasingly concerned about the safety of their food and uncertain about food production practices. Potential threats to human health related to dairy products and dairy farming include errors in pasteurization, consumption of raw milk products, contamination of milk products by emerging heat-resistant pathogens, emergence of antimicrobial resistance in zoonotic pathogens, chemical adulteration of milk, transmission of zoonotic pathogens to humans through animal contact, and foodborne disease related to cull dairy cows. Most dairy farmers feel responsible for the safety of milk and beef that originate on their farms, but linkage between farm production practices and the quality of processed products have been weak. The safety of dairy products can be enhanced by adoption of a number of management practices. Sources of microbial contamination of milk must be minimized by adoption of hygienic standards that can be easily evaluated. Uniform adoption of milking practices that reduce microbial contamination of milk should be emphasized. The diagnosis of salmonellosis or listeriosis on a dairy farm should be regarded as an indication that other potentially infected animals may be present in the herd. Coliform counts on bulk tank milk should be routinely performed as an indicator of fecal contamination. A reduction in the national regulatory limit for somatic cells in bulk tank milk should be considered based on potential enhancements in milk safety. Dairy farmers must take responsibility for the market cattle leaving their farms. The inappropriate or prophylactic use of antimicrobial agents must be minimized to ensure that antimicrobial resistance does not develop in animal pathogens. Consumers can have confidence in food safety programs on dairy farms that promote awareness and accountability for the products that are produced. (Key words: food safety, milk quality, dairy production, zoonotic pathogen)
\end{abstract}

Received July 29, 2002.

Accepted September 12, 2002. edu.
Abbreviation key: BTSCC = bulk tank somatic cell count, HACCP = hazard analysis critical control point.

\section{INTRODUCTION}

It is well established that foodborne diseases cause significant economic and social losses. In the United States, there are estimates that foodborne diseases account for millions of illnesses, hundreds of thousands of hospitalizations, and thousands of deaths each year (Mead et al., 1999). Many of the agents responsible for foodborne disease have only recently been recognized (Tauxe, 1997). Well-publicized foodborne disease outbreaks have created widespread consumer awareness of potential threats to human health from food (Anonymous, 1985, 1993, 1998). Modern communication systems have enhanced consumer awareness of outbreaks occurring throughout the world and have reduced the sense of safety associated with distance. Geographical barriers to the spread of disease have been reduced by the globalization of food systems and by the frequent movement of people and animals. Consumer confidence in existing food handling and processing systems has been reduced by the emergence of transmissible spongiform encephalopathies associated with animal products (Boor et al., 2001; Brown et al., 2001). The potential for additional animal or human pathogens to survive current food processing methods (such as pasteurization) is an area of ongoing research (Stabel, 2000, 2001; Harris and Lammerding, 2001; Pearce et al., 2001; Grant et al., 2002).

The dairy industry has been extremely successful in producing safe and nutritious products. Milk is a highly nutritious food that is ideally suited for growth of pathogenic organisms. Consumption of raw milk remains a well-identified risk factor for foodborne disease, but pasteurization has been highly effective in ensuring the safety of dairy products (Headrick et al., 1998). Even though dairy products are consumed on a daily basis, milk, ice cream, and cheese have been identified as the vehicle for less than $1.5 \%$ of all foodborne disease outbreaks investigated by the Centers for Disease Control (Bean et al., 1996). In cases involving pasteurized dairy products, errors in the pasteurization process or 
the addition of nonpasteurized eggs have frequently been identified as the route of contamination (Ryan and Nickels, 1987).

Potential threats to human health related to the dairy industry include errors during pasteurization, consumption of raw milk products, contamination of milk products by heat-resistant pathogens, chemical adulteration of milk, and foodborne disease transmission by market dairy cows. An additional concern is transmission of zoonotic pathogens to farm workers and visitors. The role of antibiotics used in animal agriculture in the development of antimicrobial resistance is controversial and increasingly scrutinized (Piddock, 1998; Khan et al., 2000; White et al., 2001). Most dairy farmers feel responsible for the safety of milk and beef that originate on their farms, but linkage between farm production practices and the quality of processed products have been weak (Payne et al., 1999). The safety of dairy products can be enhanced by adoption of a number of management practices. The objective of this paper is to outline practical interventions that can enhance the safety of dairy products and dairy farm environments.

\section{SCOPE OF DAIRY FOOD SAFETY ISSUES}

Healthy dairy cattle are considered a reservoir for several of the most important foodborne human disease pathogens (Tauxe, 1997). Nontyphoidal Salmonella spp., and Campylobacter jejuni are considered important threats to food safety because of the enormous number of illnesses they cause. Listeria monocytogenes and Escherichia coli $\mathrm{O} 157: \mathrm{H} 7$ are priority pathogens because of the severity of symptoms associated with infection and because of the number of deaths that occur in infected people. All of these pathogens are shed in cattle feces and can contaminate dairy farm premises including unpasteurized bulk tank milk (Table 1). In some instances, colonization of the udder can also contribute to contamination of bulk milk supplies. Salmonella spp., are an infrequent cause of mastitis in dairy cows but several species of Salmonella have been documented to colonize udders and shed at levels of up to 2000 organism/ml (Fontaine et al., 1980). Listeria monocytogenes has been reported to cause mastitis and can be shed in milk. A study that examined $>500$ isolates of milk obtained from coliform mastitis cases was not able to isolate O157:H7 from any of the samples and $E$. coli O157:H7 has not been recognized as a cause of mastitis (Cullor, 1997a). C. jejuni can be shed in milk, but fecal contamination of milk is a more likely route of exposure. When regulatory standards for bacterial counts in raw milk are met, pasteurization of milk is highly effective in destroying all of these organisms.

Table 1. Isolation of selected pathogens from dairy cows and dairy farm environments.

\begin{tabular}{|c|c|c|c|c|}
\hline Study & C. jejuni & Salmonella & Listeria & E. coli $\mathrm{O} 157: \mathrm{H} 7$ \\
\hline \multicolumn{5}{|l|}{ Bulk tank milk samples } \\
\hline Rohrbach et al., 1992 & $12.3 \%$ & $8.9 \%$ & $4.1 \%$ & \\
\hline Steele et al., 1997 & $0.5 \%$ & $0.2 \%$ & $2.7 \%$ & $0.9 \%$ \\
\hline Padhye \& Doyle, 1991 & & & & $10.0 \%$ \\
\hline McManus \& Lanier, 1987 & $0.4 \%$ & $4.7 \%$ & & \\
\hline Jayarao, 1999 & $9.2 \%$ & $6.1 \%$ & $4.6 \%$ & \\
\hline Warnick et al., 2001 & & $2.2 \%$ & & \\
\hline \multicolumn{5}{|l|}{ Dairy cattle feed samples } \\
\hline Warnick, et al., $2001^{1}$ & & $13.2 \%$ & & \\
\hline Skovgaard and Morgen, 1988 & & & $62 \%$ & \\
\hline \multicolumn{5}{|l|}{ Prevalence of fecal shedding in lactating dairy cows } \\
\hline Wesley et al., 2000 & $42.9 \%$ & & & \\
\hline Wells et al., 1996 & & $5.4 \%$ & & $0.9 \%$ \\
\hline Rice et al., 1997 & & & & $3.4 \%$ \\
\hline Skovgaard \& Morgen, 1988 & & & $51 \%$ & \\
\hline Huston et al., 2002 & & $6.0 \%$ & & \\
\hline \multicolumn{5}{|l|}{ Prevalence of fecal shedding in cull dairy cows } \\
\hline Wesley et al., 2000 & $30.3 \%$ & & & \\
\hline Troutt et al., 2001 & & $23.1 \%^{2}$ & & \\
\hline Wells et al., 2001 & & $14.9 \%$ & & $2.8 \%$ \\
\hline McDonough et al., 2000 & & & & $1.3 \%$ \\
\hline Rice et al., 1997 & & & & $3.9 \%$ \\
\hline \multicolumn{5}{|l|}{ Estimated prevalence of farms with shedding cows } \\
\hline Wesley et al., 2000 & $80.6 \%$ & & & \\
\hline Wells et al., 1996 & & $21.1 \%$ & & $24.2 \%$ \\
\hline Huston, et al., 2002 & & $31.0 \%$ & & \\
\hline
\end{tabular}


There are three primary routes of potential exposure of humans to these bacteria and other potential threats to human safety associated with the dairy industry: 1) ingestion of contaminated raw milk, 2) contact with beef contaminated with feces, and 3) direct contact with infected animals. Ingestion of raw milk is a high-risk behavior that is reported by a small proportion $(<2 \%)$ of the overall US population but can be a significant risk factor for specific subpopulations (Yang et al., 1998). Consumption of raw milk or raw milk products occurs frequently in dairy farm workers (Rohrbach et al., 1992) and in some ethnic communities (Reed and Grivetti, 2000). Fecal contamination of carcasses of market dairy cattle combined with consumption of undercooked hamburger is a known source of exposure for $E$. coli $\mathrm{O} 157: \mathrm{H} 7$ and several other pathogens, and some of the most deadly disease outbreaks have been associated with this route of exposure. Direct or indirect contact with infected animals is also a known risk factor for a number of zoonotic diseases. Contact with farm environment, living in an area in proximity to livestock farms, and living in an area where manure is applied to farm land have all been identified as significant risk factors for $E$. coli O157:H7 (O'Brien et al., 2001; Valcour et al., 2002). The common characteristic of these potential routes of exposure is the presence of fecal contamination, and it is intuitive that the reduction of fecal contamination of food products should be a primary objective of food safety programs.

\section{POTENTIAL CONTROL POINTS FOR DAIRY FOOD SAFETY}

There is ample evidence that microbial contamination of milk can be controlled by the use of standardized best management practices. Mastitis control programs focusing on hygienic harvest of milk have been widely adopted for at least $50 \mathrm{yr}$. Worldwide, farmers have achieved tremendous success in reducing the incidence of contagious mastitis by adopting the five basic principles of mastitis control: postmilking teat disinfection, universal dry cow antibiotic therapy, appropriate treatment of clinical cases, culling of chronically infected cows, and regular milking machine maintenance. Contagious bacteria, such as Staphylococcus aureus and Streptococcus agalactia, are now responsible for less than one-third of all mastitis cases compared with $>75 \%$ of all cases $20 \mathrm{yr}$ ago (Hillerton et al., 1995).

While most aspects of the five-point mastitis control plan have been widely adopted, many other best management practices are not widely used. Routine recording of illnesses and treatments, written standard operating procedures, routine surveillance programs that involve repeated diagnostic tests (such as microbio- logical testing of bulk tank milk) and participation in quality assurance programs have not been widely adopted across the dairy industry (Barkema et al., 1998; Wilson et al., 1998; Ruegg, 2001). Compelling reasons to adopt these practices, such as obvious financial rewards, regulatory oversight or recognizable efficacy and benefit to the farmer, are lacking. Adoption of practices to ensure food safety will face similar challenges.

\section{From HACCP to Hurdles}

Hazard analysis critical control point (HACCP) programs at the farm-level have been promoted as the key to assuring dairy farm food safety (Cullor, 1997b; Reneau et al., 1998). While HACCP programs are routinely implemented in food-processing plants, there are several aspects of HACCP that make widespread adoption on dairy farms unlikely. HACCP programs require critical multidisciplinary review of existing management processes, the establishment of limits via identification of critical control points, the use of routine surveillance procedures, effective record keeping, and documentation of standard processes. The technology to carry out on-farm HACCP programs is further limited by inadequacies and costs of existing testing methodologies (Gardner, 1997). These limitations have led some to abandon farm-level HACCP programs in favor of alternative approaches such as "Hurdle Technology" (Heggum, 2001).

Hurdle technology refers to the application of a combination of selected "hurdles" to microbiological growth combined with processing steps that maintain and improve the microbial stability and sensory quality of foods (Leistner, 2000; Heggum, 2001). Hurdles commonly used in food processing are directed at reducing growth of microorganisms present on harvested food products and include chilling, alternation in $\mathrm{pH}$, the use of competitive microorganisms and alterations in water content (Leistner, 2000). The basic concept of hurdle technology is to produce an environment that is hostile to the growth of microorganisms. The concept of on-farm hurdles may be extended to include best management practices focused on the exclusion of bacteria from raw milk supplies. The use of "hurdles" to microbial growth is implicit in the primary regulatory document that governs the production of milk in the United States. The Pasteurized Milk Ordinance specifies the standards for production, handling, transportation, processing, testing, and sale of milk (Anonymous, 1999). This document includes recommendations that are expected to limit microbial contamination of milk and many of the concepts within it can be directly extrapolated to control other food safety risks. 


\section{PRACTICAL INTERVENTIONS FOR DAIRY FARMS}

The North American dairy industry currently produces and markets some of the safest and most nutritious food products in the world. To maintain these standards and adapt to evolving consumer expectations there are a number of practical on-farm management interventions that can be adopted to enhance dairy product food safety.

1. Reduce sources of microbial contamination of milk. Dairy farmers must continue to place hurdles in the way of microbial contamination of milk. Excellent hygienic standards for housing and milking centers and cleanliness of cows result in reduced opportunities for growth and transmission of pathogenic bacteria. Routine assessment of farm hygiene through the use of scoring systems can be used to motivate farmers and to document responses to interventions (such as changes in bedding type or bedding frequency). Udder hygiene scoring charts have been developed (Figure 1), and cows with dirtier udders have significantly higher prevalence of infection with mastitis pathogens (Schreiner and Ruegg, 2002, unpublished). It is highly likely that other microbial contaminants are also associated with dirtier udders and udder hygiene scoring should be used as part of routine quality assurance programs on dairy farms. The source of microbial contamination is often the housing area of the cows. Hygiene scoring systems for animal facilities have been reported but are not routinely used (Barkema et al., 1998). The amount of manure present in the back of cow stalls, the dirtiness of the milking parlor, and the thickness of bedding can be routinely assessed. Improvements in hygiene scores for facilities and udders can be used as a key indicator of on-farm pathogen reduction programs.

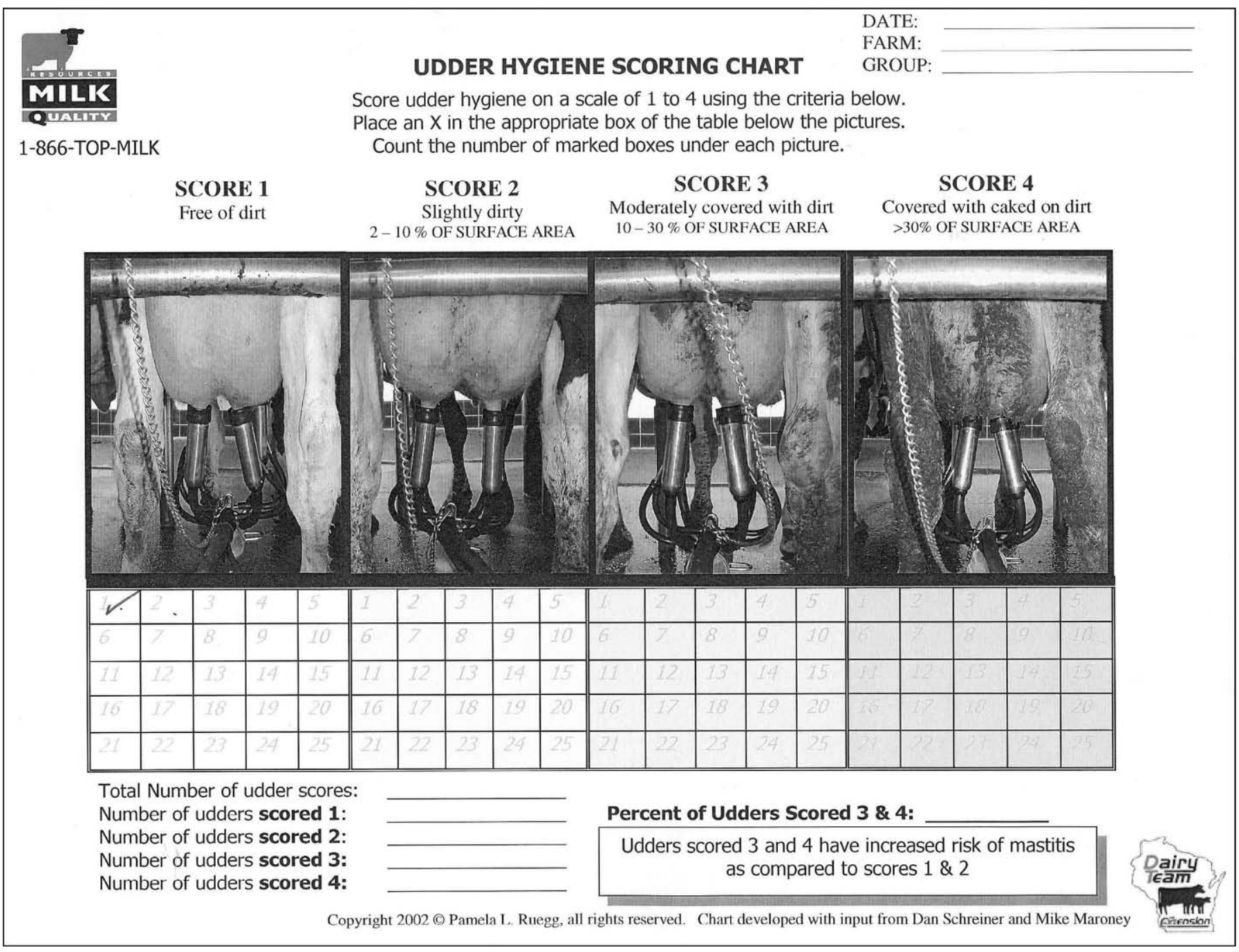

Figure 1. Udder hygiene scoring chart (from Schriener and Ruegg, 2002) 
Table 2. Premilking procedures by type of milking facility for $315^{1}$ Wisconsin dairy farmers returning written surveys in Nov. 1998 - Jan. 1999.

\begin{tabular}{|c|c|c|c|c|}
\hline & Stall Barn ${ }^{2}$ & Parlor & Chi-square & $P$-value \\
\hline Predipping & $60 \%$ & $85 \%$ & 22.8 & $<0.001$ \\
\hline Washing udder with a sanitizer & $41 \%$ & $10 \%$ & 35.4 & $<0.001$ \\
\hline Forestripping & $57 \%$ & $73 \%$ & 8.2 & 0.004 \\
\hline No premilking preparation & $2 \%$ & $0 \%$ & & \\
\hline
\end{tabular}

${ }^{1} 338$ herds participated in the survey, 315 reported data about milking routine.

${ }^{2}$ Sum of pre-dipping and washing with a sanitizer is $>100 \%$ because some herds utilize both practices.

2. Uniform adoption of milking practices that reduce contamination of milk. Many farms are currently using hygienic milking practices and the effective use of predipping and forestripping has been shown to enhance milk safety. The use of predipping using iodine has been demonstrated to reduce standard plate counts and coliform counts in raw milk by five- and six-fold, respectively, as compared to other methods of premilking udder preparation (Galton et al., 1986). The overall reduction of microbial loads in raw milk through the use of predipping should result in reduced numbers of zoonotic pathogens. Predipping has been shown to reduce the risk of Listeria monocytogenes in milk filters by almost four-fold (Hassan et al., 2001). The examination of milk before attaching milking units is necessary to ensure that all abnormal milk is diverted from the human food chain and should be a standard food safety practice on ALL farms. Similar to predipping, the use of forestripping has been shown to significantly reduce (2.5 times less likely) the risk of contamination of milk with L. monocytogenes (Hassan et al., 2001). While both predipping and forestripping are uniformly recommended milking procedures, considerable numbers of herds have abandoned or never adopted these practices. An analysis of 338 written surveys of Wisconsin dairy farmers attending extension meetings (performed in November 1998 through January 1999) indicated that significant proportions of dairy farms were not utilizing either of these procedures (Table 2). There is some indication that increased herd sizes and management style can be related to poorer hygienic practices. In the Netherlands, farms having a management style characterized as "quick and dirty" were slightly larger than farms with a management style characterized as "clean and accurate" (Barkema et al., 1999). Management style was highly associated with bulk tank SCC (BTSCC), as $73 \%$ of herds with high BTSCC were managed by farmers classified as "quick and dirty." Industry trends toward reduced premilking cow preparation and increased parlor throughput may result in reductions in hygiene and increased food safety risks.

3. Identification of high-risk practices and herds. Dairy cattle are the reservoir for several im- portant human pathogens and the diagnosis of Salmonella spp., or $L$. monocytogenes in one or more animals should be regarded as an indication that other potentially infected animals are present in the dairy herd. Fecal shedding of these pathogens from asymptomatic animals should be presumed and every effort should be made to identify high-risk animals (calves, sick cows, fresh cows, and designated cull cows). The clinical diagnosis of Salmonellosis in a dairy herd within the previous year has been shown to increase the risk of fecal shedding of Salmonella spp. in asymptomatic animals by 4.6 times (Huston, et al., 2002). High-risk practices for Salmonella vary by serotype but include the presence of carrier cows, use of recycled flush water, purchase of contaminated feedstuffs, use of contaminated water for irrigation, and access of rendering trucks to animal housing areas (House and Smith, 1992) Campylobacter jejuni is regularly shed from asymptomatic animals and any isolation of the organism on a dairy should be viewed as evidence that the pathogen is a likely fecal contaminant (Ruegg et al., 2001). Employees should be educated regarding potential occupational risks, and the importance of personal hygiene should be stressed.

4. Perform coliform counts. Coliform counts of raw bulk tank milk can be routinely performed to identify bacteria that originate from fecal contamination of milk. Coliform bacteria can contaminate milk through poor udder preparation or unhygienic handling of the milking machines. Coliform counts should be less than $100 \mathrm{cfu} / \mathrm{ml}$ for milk intended to be pasteurized before consumption and less than $10 \mathrm{cfu} / \mathrm{ml}$ if raw milk will be consumed. Coliforms can incubate in residual films left on milk contact surfaces such as milking pipelines or equipment. Coliform counts greater than $1000 \mathrm{cfu} / \mathrm{ml}$ suggest incubation, and the equipment cleaning process should be investigated. Fecal contamination of milk supplies appears to occur frequently. Coliform counts exceeded $100 \mathrm{cfu} / \mathrm{ml}$ for $23.6 \%$ of 855 samples of raw milk obtained from bulk milk samples of New York dairy farms (Boor et al., 1998).

5. Reduced national SCC limits. The US BTSCC regulatory limit of 750,000 cells per milliliter is considerably higher than regulatory limits of similar regions 
such as the European Union (400,000 cells per milliliter) or Canada (500,000 cells per milliliter) (Hillerton, 2001 and MacNaughton, 2001). Growth of most microorganisms is favored by the presence of organic compounds, moderate or warm temperatures, adequate oxygen, and neutral $\mathrm{pH}$. All of these conditions are present in the modern dairy farm and are most commonly recognized when mastitis problems develop. There is ample evidence that increased prevalence of subclinical mastitis in a dairy herd (as demonstrated by high BTSCC) is indicative of management practices associated with reduced food safety. Monthly BTSCC values were higher in herds where verotoxigenic $E$. coli and Listeria monocytogenes were cultured from bulk tanks as compared to herds negative for those pathogens (Steele et al., 1997). Hygienic practices on herds with higher SCC values are generally poorer than hygienic practices on herds with lower SCC values (Barkema et al., 1998). Milking facilities, cow housing areas, and the udders of cows from herds with higher SCC values have been demonstrated to be dirtier and more soiled with manure than with cows and facilities from herds with lower SCC values (Barkema et al., 1998). Poor hygienic practices of the milking herd appear to be indicative of an overall lack of hygiene standards. The transmission of potential pathogens to youngstock by feeding milk from infected cows or milk containing antibiotic residues and the use of dirty drinking buckets are additional practices that were found to occur more frequently in herds with higher SCC values than with herds with SCC values of less than 150,000 cells per milliliter (Barkema et al., 1998). High BTSCC have also been linked to the occurrence of other indicators of poorer milking management. The risk of incurring a violative antibiotic residue is two to seven times higher for herds with BTSCC values above 400,000 cells per milliliter as compared to herds with BTSCC values of less than 250,000 cells per milliliter (Ruegg and Tabone, 2000). In the United States, BTSCC limits for grade A milk were reduced from 1,500,000 cells per milliliter to 1,000,000 cells per milliliter in 1986 and further reduced to 750,000 cells per milliliter in 1993 (Spomer, 1998). Compliance with previous reductions in national regulatory limits for BTSCC was rapidly achieved, and it is likely that continued reductions in BTSCC regulatory limits would further improve the image of safety and quality of US dairy products.

6. Market only clean and healthy cull cattle with minimal BCS standards. Microbial contamination of ground beef with pathogens is a news item that merits national attention (Schlosser, 2002). Market cattle (cull dairy cows) account for approximately $18 \%$ of US ground beef and consumers expect the animals to be healthy and free of contaminants (Anonymous, 1996).
Market cattle may represent the greatest risk to the safety and quality image of the dairy industry. Of 413 California dairy farmers that responded to a mail survey, 23 and $71 \%$ reported that cow carcasses had been condemned during the five previous years due to antibiotic residue violations or infection and illness, respectively (Payne et al., 1999). Fifty-seven percent of the responding dairy farms reported they sometimes shipped sick cows rather than treat them. The relatively high proportion of market cattle shedding potentially zoonotic pathogens is evidence of the potential for contamination of meat supplies (Table 1). Low BCS $(<2.5$ on a five-point scale) has been used as a predictor of illness in market cattle and it is likely that buyers of the future may reject overly thin cows (Rossiter and Henning, 2001). Farms should work with their veterinarians to establish culling plans that include realistic treatment plans and standards for minimum BCS.

7. Responsible antimicrobial usage. Antibiotic usage on dairy farms has been blamed for the emergence of antibiotic resistance in human pathogens (Spika et al., 1987; White et al., 2001). Despite decades of therapeutic and prophylactic usage, there is no evidence that antimicrobial resistance of mastitis pathogens is increasing in a consistent manner (Erskine et al., 2002; Makovec and Ruegg, 2002). However, the use of subtherapeutic levels of antimicrobial agents in foodproducing animals (such as tetracycline-containing milk replacers) is increasingly scrutinized and will likely require justification for continued use (Angulo and Griffin, 2000). The vast majority of dairy farms use antibiotics in a responsible fashion. However, surveys of dairy farms consistently indicate the need for improved communication and consultation with local veterinarians in the development of treatment protocols and the use of extra-label products (Table 3). All dairy farms should have written treatment plans that have been negotiated with their local veterinarian and are routinely reviewed and updated. The objective of the treatment plan should be to ensure the health and wellbeing of the animals while limiting antibiotic use to justifiable uses. When isolation of bacterial pathogens is possible, susceptibility tests that generate quantitative outcomes (i.e., minimum inhibitory concentrations) should be performed to guide selection of appropriate antibiotics.

\section{IMPLEMENTATION}

The universal implementation of these interventions is a major challenge for the complex and highly diverse dairy industry. Virtually all dairy producers must understand the linkage between animal management and the safety and quality of food products. It is unlikely 
Table 3. Selected measures of veterinary involvement in dairy farms.

\begin{tabular}{llll}
\hline Characteristic & State & Percent & Reference \\
\hline Percent of farms with written quality assurance program & CA & 25 & Payne, et al., 1999 \\
Veterinarian participates in QA program & CA & 46 & 46 \\
No records or temporary records of drug treatments kept & CA & 80 & 25 \\
Use veterinarian to obtain withholding times for extra-label drug treatments & CA & WI & 29 \\
Have a written treatment protocol & WI & Ruegg, 2001 \\
Routinely consult veterinarian about milk quality & & \\
\hline
\end{tabular}

that education alone will motivate dairy farmers to voluntarily adopt practices for which they don't recognize an immediate economic return. In one study, management practices of herd managers familiar with Johnes's disease were similar to management practices used by managers unfamiliar with the disease (Wells and Wagner, 2000). In an attempt to reduce liability concerns, corporate purchasers of animal-derived products will most likely slowly take steps to identify high-risk practices on source farms and seek out suppliers who can certify the use of lower risk practices. The move toward universal animal ID systems with traceback capability confirm industry interest in this issue. Dairy industry experiences with antibiotic residue violations in bulk milk are evidence of the ability of the industry to rapidly respond to an accurate traceback mechanism. Since 1994, a sample of milk has been collected from all bulk tanks at the time the milk is loaded. Since adopting this regulation, the number of bulk milk antibiotic violations has fallen by almost $40 \%$ (Figure 2).

\section{CONCLUSIONS}

The North American dairy industry has a long history of marketing safe and nutritious dairy products. Con-

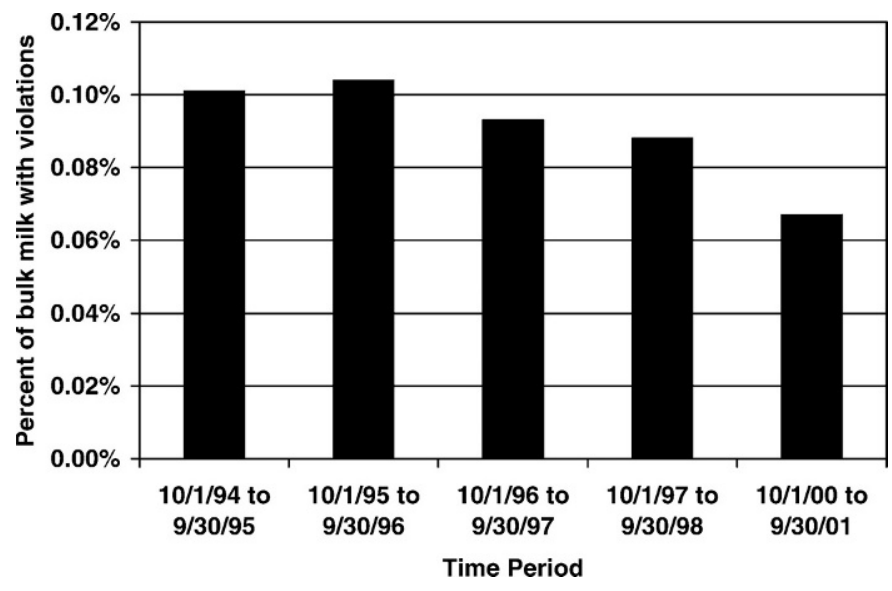

Figure 2. Percentage of bulk milk pick-up tankers positive for antibiotic residue violations (From the National Milk Drug Residue Database Annual Report, GLH, Inc., Lighthouse Point, FL, 33064). sumer concerns about the safety of food products derived from livestock are increasing and food retailers are looking for mechanisms to reduce their liability. The adoption of "hurdles" to microbial contamination of food products and widespread implementation of verifiable risk reduction practices on dairy farms can help to allay consumer fears. Many of the suggested practices are currently used on dairy farms today and further adoption of these practices will help to maintain the generally positive image of our dairy industry.

\section{REFERENCES}

Angulo, F. J., and P. M. Griffin. 2000. Changes in antimicrobial resistance in Salmonella enterica serovar typhimurium. Emerg. Infect. Dis. 6:436.

Anonymous. Centers for Disease Control and Prevention. 1985. Listeriosis outbreak associated with Mexican-Style cheese-California. Morbid. Mortal. Weekly Rep. 34:357-359.

Anonymous. Centers for Disease Control and Prevention. 1993. Update: Multistate Outbreak of Escherichia coli O157:H7 infections from hamburgers-Western United States, 1992-1993. Morbid. Mortal. Weekly Rep. 42:258-263.

Anonymous. 1996. Economic opportunities for dairy cow culling management options. US Dept. Agriculture., Anim. Plant Health Inspection Serv. http://www.aphis.usda.gov/vs/ceah/cahm/ Dairy_Cattle/d96culltxt.htm. Accessed Sept. 2002.

Anonymous. Centers for Disease Control and Prevention. 1998. Multistate outbreak of listeriosis - United States, Morbid. Mortal. Weekly Rep. 42:1085.

Anonymous. 1999. Pasteurized Milk Ordinance, 1999 Revision. U.S. Dept. of Health and Human Services. http://vm.cfsan.fda.gov/ ear/p-nci.html. Accessed Sept. 2002.

Barkema, H. W., Y. H. Schukken, T. J. G. M. Lam,, M. L. Beiboer, G. Benedictus, and A. Brand. 1998. Management practices associated with low, medium, and high somatic cell counts in bulk milk. J. Dairy Sci. 81:1917-1927.

Barkema, H. W., J. D. vand der Ploeg, Y. H. Schukken, T. J. G. M. Lam, G. Benedictus, and A. Brand. 1999. Management style and its association with bulk milk somatic cell count and incidence rate of clinical mastitis. J. Dairy Sci. 82:1655-1663.

Bean, N. H., J. S. Goulding, C. Lao, and F. J. Angulo. 1996. Surveillance for foodborne-disease outbreaks-United States, 19881992. Morbid. Mortal. Weekly Rep. 45(SS-5):1-73.

Boor, K. J. 2001. Fluid dairy product quality and safety: looking to the future. J. Dairy Sci. 84:1-11.

Boor, K. J., D. P. Brown, S. C. Murphy, S. M. Kozlowski, and D. K. Bandler. 1998. Microbiological and chemical quality of raw milk in New York State. J. Dairy Sci. 81:1743-1748.

Brown, P., R. G. Will, R. Bradley, D. M. Asher, and L. Detwiler. 2001. Bovine spongiform encephalopathy and variant Creutzfeldt-Jakob disease: background, evolution, and current concerns. Emerg. Infect. Dis. 7:6-14. 
Cullor, J. S. 1997a. Mastitis and dairy environment pathogens of public health concern. Pages 20-32 in Proc. Natl. Mastitis Counc., Annu. Mtg. Natl. Mast. Counc., Madison, WI.

Cullor, J. S. 1997b. HACCP (Hazard Analysis Critical Control Points): Is it coming to the dairy? J. Dairy Sci. 80:3449-3452.

Erskine, R. J., R. D. Walker, C. A. Bolin, P. C. Bartlett, and D. G. White. 2002. Trends in antibacterial susceptibility of mastitis pathogens during a seven-year period. J. Dairy Sci. 85:1111-1118.

Fontaine, R. E., M. L. Cohen, W. T. Martin, and T. M. Vernon. 1980 Epidemic salmonellosis from cheddar cheese-surveillance and prevention. Am. J. Epidemiol. 111:247.

Galton, D. M., L. G. Petersson, and W. G. Merrill. 1986. Effects of premilking udder preparation practices on bacterial counts in milk and on teats. J. Dairy Sci. 69:260-266.

Gardner, I. A., 1997. Testing to fulfill HACCP (Hazard Analysis Critical Control Points) requirements: principles and examples. J. Dairy Sci. 80:3453-3457.

Grant, I. R., E. I. Hitchings, A. McCarthney, F. Ferguson, and M. T. Rowe. 2002. Effect of commercial-scale high-temperature, shorttime pasteurization on the viability of Mycobacterium paratuberculosis in naturally infected cows' milk. Appl. Environ. Microbiol. 68:602-607.

Harris, J. E., and A. M. Lammerding. 2001. Crohn's disease and Mycobacterium avium sbsp. paratuberculosis: current issues. J. Food Prot. 64:2103-2110.

Hassan, L., H. O. Mohammed, and P. L. McDonough. 2001. Farmmanagement and milking practices associated with the presence of Listeria monocytogenes in New York state dairy herds. Prev. Vet. Med. 51:63-73.

Headrick, M. L., S. Korangy, N. H. Bean, F. J. Angulo, S. F. Altekruse, M. E. Potter, and K. C. Klontz. 1998. The epidemiology of raw milk-associated foodborne disease outbreaks reported in the United States, 1973 through 1992. Am. J. Pub. Health 88:1219-1221.

Heggum, C. 2001. Trends in hygiene management-the dairy sector example. Food Control 12:241-246.

Hillerton, J. E. 2001. Meeting somatic cell count regulations in the European Union. Pages 47-53 in Proc. Natl. Mastitis Counc. Natl. Mast. Counc. Inc., Madison, WI

Hillerton, J. E., A. J. Bramley, R. T. Staker, and C. H. McKinnon. 1995. Patterns of intramammary infection and clinical mastitis over a 5-year period in a closely monitored herd applying mastitis control measures. J. Dairy Res. 62:39-50.

House, J. K., and B. P. Smith. 1997. Salmonella current concepts. Proc. 30th Annu. Mtg. Am. Assoc. Bov. Pract. 30:28-32.

Huston, C. L., T. E. Wittum, B. C. Love, and J. E. Keen. 2002. Prevalence of fecal shedding of Salmonella spp in dairy herds. J. Am. Vet. Med. Assoc. 220:645-649.

Jayarao, B. 1999. A study on the prevalence of pathogens in bulk tank milk. Pages 148-149 in Proc. Natl. Mastitis Counc. Natl. Mast. Counc. Inc., Madison, WI.

Khan, S. A., M. S. Nawaz, A. A. Khan, R. S. Steele, and C. E. Cerniglia. 2000. Characterization of erythromycin-resistant methylase genes from multiple antibiotic resistant Staphylococcus spp. isolated from milk samples of lactating cows. Am. J. Vet. Res. 61:1128-1132.

Leistner, L. 2000. Basic aspects of food preservation by hurdle technology. Intl. J. Food Microbiol. 55:181-186.

MacNaughton, G. Canadian approach to SCC regulations-The mechanics. 2001. Pages 54-58 in Proc. Natl. Mastitis Counc. Natl. Mast. Counc. Inc., Madison, WI.

Makovec J. A. and P. L. Ruegg. 2002. Antimicrobial resistance patterns of bacteria cultured from milk samples in Wisconsin from 1994 to 2001. J. Dairy Sci. 80(suppl.1):84 (Abstr.).

McDonough, P. L., C. A. Rossiter, R. B Rebhun, S. M. Stehman, D. H. Lein, and S. J. Shin. 2000. Prevalence of Escherichia coli O157:H7 from cull dairy cows in New York State and comparison of culture methods used during preharvest food safety investigations. J. Clin. Microbiol. 38:318-322.

McManus, C., J. M. Lanier. 1987. Salmonella, Campylobacter jejuni, and Yersinia enterocolitica in raw milk. J. Food Prot. 50:51.
Mead, P. S., L. Slutsker, V. Dietz, L. F. McCaig, J. S. Bresee, C. Shapiro, P. M. Griffin, and R. V. Tauxe. 1999. Food-related illness and death in the United States. Emer. Inf. Dis. 5:607-625.

O'Brien, S. J., G. K. Adak, and C. Gilham. 2001. Contact with farming environment as a major risk factor for shiga toxin (vero cytotoxin)producing Escherichia coli O:157 infection in humans. Emerg. Infect. Dis. 7:1049-1051.

Padhye, N. V., and M. P. Doyle, 1991. Rapid procedure for detecting enterohemorrhagic Escherichia coli O157:H7 in food. Appl. Environ. Microbiol. 57:2693-2698.

Payne, M., C. M. Bruhn, B. Reed, A. Scearce, and J. O’Donnell. 1999 On-farm quality assurance programs: a survey of producer and industry leader opinions. J. Dairy Sci. 82:2224-2230.

Pearce, L. E., H. T. Truong, R. A. Crawford, G. F. Yates, S. Cavaignac, and G. W. deLisle. 2001. Appl. Environ. Microbiol. 67:3964-3969.

Piddock, L. J. 1998. Fluoroquinolone resistance: overuse of fluoroquinolones in human and veterinary medicine can breed resistance. B. Med. J. 317:1029-1030.

Reed, B. A., and L. E. Grivetti. 2000. Controlling on-farm inventories of bulk-tank raw milk-an opportunity to protect public health. J. Dairy Sci. 83:2988-2991.

Reneau, J. K., W. E. Marsh, R. H. Craven, W. W. Coleman, D. W. Richarson, J. Friertag, W. Stoll, and D. Bartholomew. 1998. DairyTQM: a tool for use in on-farm dairy HACCP programs. Pages 236-237 in Proc. Natl. Mast. Counc., St. Louis, MO. Natl. Mast. Counc. Madison, WI.

Rice, D. H., E. D. Ebel, D. D. Hancock, T. E. Besser, D. E. Herriott, and L. V. Carpenter. 1997. Escherichia coli O157:H7 in cull dairy cows on farm and at slaughter. J. Food Prot. 60:1386-1387.

Rohrback, B. W., F. A. Draughon, P. M. Davidson, and S. P. Oliver, 1992. Prevalence of Listeria monocytogenes, Campylobacter jejuni, Yersinia enterocolitica, and Salmonella in bulk tank milk: risk factors and risk of human exposure. J. Food Prot. 55:93-97.

Rossiter, C. A., and W. R. Henning. 2001. Isolation of Mycobacterium paratuberculosis from thin market cows at slaughter. J. Dairy Sci. 84(Suppl. 1):113. (Abstr.)

Ruegg, P. L. 2001. Activities and outcomes of Wisconsin dairy farms participating in team-based milk quality programs. Proc. 2nd Intl., Symp. Mast. Milk Quality. Vancouver, BC, Canada, Sept. 13-15, 2001, Natl. Mast. Coun., Madison, WI.

Ruegg, P. L., J. B. Kaneene, L. D. Warnick, S. J. Wells, A. M. Saeed, C. Fossler, and L. Halbert. 2001. Weekly shedding of Campylobacter jejuni on 12 Midwest and Northeast dairy farms. J. Dairy Sci. 84(supp 1):114. (Abstr.).

Ruegg, P. L., and T. J. Tabone. 2000. The relationship between antibiotic residue violations and somatic cell counts in Wisconsin dairy herds. J. Dairy Sci. 83:2805-2809.

Ryan, C. A., and M. K. Nickels. 1987. Massive outbreak of antimicrobial-resistant salmonellosis traced to pasteurized milk. J. Am. Med. Assoc. 258:3269-3274.

Schlosser, E. 2002. Hamburger with those fries? Buyers beware. USA Today, July 10, 2002, pp 11A.

Skovgaard, N., and C. A. Morgen. 1988. Detection of Listeria spp. in feces from animals, in feeds, and in raw foods of animal origin. Intl. J. Food Microbiol. 6:229-242.

Spika, J. S., S. H. Waterman, G. W. Hoo, M. E. St. Louis, R. E. Pacer, S. M. James, M. L. Bissett, L. W. Mayer, J. Y. Chiu, and B. Hall. 1987. Chloramphenicol-resistant SalmonellaNewport traced through hamburger to dairy farms. A major persisting source of human salmonellosis in California. N. Eng. J. Med. 316:565-570.

Spomer, D. R. 1998. Bridging the gap between public health and consumer demand for high quality product. Pages 44-46 in Proc. Natl. Mast. Counc., Madison, WI.

Stabel, J. R. 2000. Johne's diseases and milk: Do consumers need to worry? J. Dairy Sci. 83:1659-1663.

Stabel, J. R. 2001. On-farm batch pasteurization destroys Mycobacterium paratuberculosis in waste milk. J. Dairy Sci. 84:524-527.

Steele, M. L., W. B. McNab, C. Poppe, W. Mansel, W. Griffiths, S. Chen, S. A. Degrandis, L. C. Fruhner, C. A. Larkin, J. A. Lynch, and J. A. Odumeru. 1997. Survey of Ontario bulk tank raw milk for food-borne pathogens. J. Food Prot. 60:1341-1346. 
Tauxe, R. V. 1997. Emerging foodborne diseases: an evolving public health challenge. Emerg. Infect. Dis. 4:425-434.

Troutt, H. F., J. C. Galland, B. I. Osburn, R. L. Brewer, R. K. Braun, J. A. Schmitz, P. Sears, A. B. Childers, E. Richey, E. Mather, M. Gibson, K. Murthy, and A. Hogue. 2001. Prevalence of Salmonella spp. in cull (market) dairy cows at slaughter. J. Am. Vet. Med. Assoc. 219:1212-1215.

Valcour, J. E., P. Michel, S. A. McEwen, and J. B. Wilson. 2002. Associations between indicators of livestock farming intensity and incidence of human shiga toxin-producing Escherichia coli infection. Emerg. Infect. Dis. 8:252-257.

Warnick, L. D., J. B. Kaneene, P. L. Ruegg, S. J. Wells, M. Saeed, C. Fossler, and L. Halbert. 2001. Salmonella isolation on 12 Midwest and Northeast dairy farms. J. Dairy Sci. 84(Supp. 1):113(Abstr.).

Wells, S., P. J. Fedorka-Cray, T. Besser, P. McDonough, and B. Smith. 1996. E. Coli O157 and Salmonella-Status on U.S. Dairy Operations. Available online http://www.aphis.usda.gov/vs/ceah/cahm/ Dairy_Cattle/ecosalm98.htm. Accessed February 2003.

Wells, S. J., P. J. Fedorka-Cray, D. A. Dargatz, K. Ferris, and A. Green. 2001. Fecal shedding of Salmonella spp. by dairy cows on farm and at cull cow markets. J. Food Prot. 64:3-11.

Wells, S. J., and Wagner, B. A. 2000. Herd-level risk factors for infection with Mycobacterium paratuberculosis in U.S. dairies and association between familiarity of the herd manager with the disease and prior diagnosis of the disease in that herd and use of preventive measures. J. Am. Vet. Med. Assoc. 216:1450-1457.

Wesley, I. V., S. J. Wells, K. M. Harmon, A. Green, L. SchroederTucker, M. Glover, and I. Siddique. 2000. Fecal shedding of Campylobacter and Aerobacter spp. in dairy cattle. Appl. Environ. Microbiol. 66:1994-2000.

White, D. G., S. Zhao, R. Sudler, S. Ayers, S. Friedman, S. Chen, P. F. McDermott, S. McDermott, D. D. Wagner, and J. Meng. 2001. The isolation of antibiotic-resistant salmonella from retail ground meats. New Engl. J. Med. 345:1147-1154.

Wilson, D. J., P. M. Sears, and L. J. Hutchinson. 1998. Dairy producer attitudes and farm practices used to reduce the likelihood of antibiotic residues in milk and dairy beef: A five state survey. Large Anim. Pract. 19:24-30.

Yang, S., M. G. Leff, D. McTague, K. A. Horvath, J. Jackson-Thompson, T. A. Melnik, M. C. Gildemaster, D. L. Ridings, S. F. Altedruse, and F. Angulo. 1998. Multistate surveillance for food-handling, preparation and consumptive behaviors associated with foodborne disease: 1995 and 1996 BRFSS food-safety questions. 1998. Morb. Mort. Weekly Rep., 47(SS-4):33-54. CDC, Atlanta GA. 